\title{
Article \\ Cellulose Nanocrystals/Chitosan-Based Nanosystems: Synthesis, Characterization, and Cellular Uptake on Breast Cancer Cells
}

\author{
Ricardo J. B. Pinto ${ }^{1}$, Nicole S. Lameirinhas ${ }^{1}$, Gabriela Guedes ${ }^{1}{ }^{(}$, Gustavo H. Rodrigues da Silva ${ }^{1}$, \\ Párástu Oskoei $^{2}$, Stefan Spirk ${ }^{3}{ }^{\circledR}$, Helena Oliveira ${ }^{2}$, Iola F. Duarte ${ }^{1}$ (), Carla Vilela ${ }^{1, * \mathbb{C}}$ and Carmen S. R. Freire ${ }^{1, *}$
}

1 Department of Chemistry, CICECO-Aveiro Institute of Materials, University of Aveiro, 3810-193 Aveiro, Portugal; r.pinto@ua.pt (R.J.B.P.); nicoleslameirinhas@ua.pt (N.S.L.); gabriela.guedes@ua.pt (G.G.); gustavohrs@ua.pt (G.H.R.d.S.); ioladuarte@ua.pt (I.F.D.)

2 Department of Biology, CESAM-Centre for Environmental and Marine Studies, University of Aveiro, 3810-193 Aveiro, Portugal; parastu.oskoei@ua.pt (P.O.); holiveira@ua.pt (H.O.)

3 Institute of Bioproducts and Paper Technology, Graz University of Technology, Inffeldgasse 23, 8010 Graz, Austria; stefan.spirk@tugraz.at

* Correspondence: cvilela@ua.pt (C.V.); cfreire@ua.pt (C.S.R.F.)

check for updates

Citation: Pinto, R.J.B.;

Lameirinhas, N.S.; Guedes, G.; Rodrigues da Silva, G.H.; Oskoei, P.; Spirk, S.; Oliveira, H.; Duarte, I.F.; Vilela, C.; Freire, C.S.R. Cellulose Nanocrystals/Chitosan-Based

Nanosystems: Synthesis,

Characterization, and Cellular Uptake on Breast Cancer Cells. Nanomaterials 2021, 11, 2057. https://doi.org/10.3390/nano 11082057

Academic Editor: Hirotaka Koga

Received: 18 June 2021

Accepted: 9 August 2021

Published: 12 August 2021

Publisher's Note: MDPI stays neutral with regard to jurisdictional claims in published maps and institutional affiliations.

Copyright: (C) 2021 by the authors. Licensee MDPI, Basel, Switzerland. This article is an open access article distributed under the terms and conditions of the Creative Commons Attribution (CC BY) license (https:// creativecommons.org/licenses/by/ $4.0 /)$.
Abstract: Cellulose nanocrystals (CNCs) are elongated biobased nanostructures with unique characteristics that can be explored as nanosystems in cancer treatment. Herein, the synthesis, characterization, and cellular uptake on folate receptor (FR)-positive breast cancer cells of nanosystems based on CNCs and a chitosan (CS) derivative are investigated. The physical adsorption of the CS derivative, containing a targeting ligand (folic acid, FA) and an imaging agent (fluorescein isothiocyanate, FITC), on the surface of the CNCs was studied as an eco-friendly methodology to functionalize CNCs. The fluorescent CNCs/FA-CS-FITC nanosystems with a rod-like morphology showed good stability in simulated physiological and non-physiological conditions and non-cytotoxicity towards MDA-MB-231 breast cancer cells. These functionalized CNCs presented a concentration-dependent cellular internalization with a 5-fold increase in the fluorescence intensity for the nanosystem with the higher FA content. Furthermore, the exometabolic profile of the MDA-MB-231 cells exposed to the CNCs/FA-CS-FITC nanosystems disclosed a moderate impact on the cells' metabolic activity, limited to decreased choline uptake and increased acetate release, which implies an anti-proliferative effect. The overall results demonstrate that the CNCs/FA-CS-FITC nanosystems, prepared by an eco-friendly approach, have a high affinity towards FR-positive cancer cells and thus might be applied as nanocarriers with imaging properties for active targeted therapy.

Keywords: cellulose nanocrystals; chitosan; folic acid; fluorescein isothiocyanate; nanosystems; physical adsorption; cellular uptake; cellular exometabolomics; folate receptor-positive cancer cells

\section{Introduction}

Polysaccharides are natural polymers composed of monosaccharides linked by glycosidic bonds that hold great promise as eco-friendly building-blocks to develop advanced functional materials [1]. Within the vast portfolio of polysaccharides, cellulose (i.e., linear homopolysaccharide composed of $\beta$-D-glucopyranose units linked by $\beta-(1,4)$ glycosidic bonds) is amongst the most studied natural polymer in multiple fields of research [2-5]. This polysaccharide, and particularly its nanoscale forms, viz. cellulose nanocrystals (CNCs), cellulose nanofibrils (CNFs) and bacterial nanocellulose (BNC) [6], are showing incredible potential as precursors of nanomaterials for a deluge of applications, including in the fight against cancer [7-9]. In fact, the number of developed systems for cancer diagnosis and treatment $[7,9,10]$ is increasing at a fast pace since this large group of diseases is the second leading cause of death globally, with ca. 10 million deaths in 2020 [11,12]. 
CNCs have a rod-like morphology [13] and are of particular relevance in this context. Recent studies have demonstrated that the shape of the nanocarriers is an important parameter for their efficiency, and that elongated or filamentous nanostructures present several benefits over spherical ones in terms of surface area-to-volume ratio, rate of clearance from the body and elimination mechanism, as well as an enhanced uptake rate by tumor cells [14-17]. Moreover, CNCs are rich in hydroxyl groups that enable easy coupling (covalent and non-covalent) of targeting, imaging, and therapeutic agents $[9,18]$ to actively target cancerous cells [19].

As an example, Roman and co-workers have looked extensively into the use of CNCs as nanocarriers by the functionalization of these elongated nanostructures solely with fluorescein isothiocyanate (FITC) as an imaging agent [20-22] or with both FITC and folic acid (FA) as imaging and targeting agents [23-25], respectively. These authors showed the potential of these nanosystems for the active targeted delivery of chemotherapeutic agents to folate receptor (FR)-positive cancer cells, such as human (DBTRG-05MG, H4) and rat (C6) brain tumor cells [23], KB and human breast cancer cells (MDA-MB-468) [24,25]. Following the same idea, Raja et al. [26] chemically modified CNCs via covalent tethering of PEGylated biotin (targeting ligand) and perylenediimide (imaging agent) and demonstrated their aptness for cell labelling and imaging of fundamental cells of the immune system (J774A.1 macrophages and primary DCs), the connective tissue (NIH-3T3 fibroblasts), and a severe pathological state (HeLa adenocarcinoma cells).

Despite the promising results of the previously enumerated studies, the functionalization of the CNCs nanosystems was mostly performed via multiple synthesis steps and with fairly toxic reagents [20-26], and thus the need for alternative methodologies [18,27] is of utmost importance. Therefore, the use of CNCs in conjunction with a chitosan (CS, i.e., linear heteropolysaccharide obtained from chitin via $N$-deacetylation [28]) derivative with targeting and imaging ligands seems an interesting approach (inspired by their opposite surface charge) that has never been addressed before. In this scenario, the present study describes the synthesis, characterization, and cellular uptake on breast cancer cells (MDA-MB-231 cell line) of a dual polysaccharide nanosystem based on CNCs and a CS derivative with opposite surface charges. The physical adsorption of the chitosan derivative, containing targeting (FA) and imaging (FITC) ligands, on the surface of the CNCs was studied as an environmentally friendly approach to engineer CNCs nanosystems with enhanced cellular internalization by MDA-MB-231 cells. The CNCs nanosystems were characterized in terms of structure, optical properties, fluorescence, stability in simulated physiological and non-physiological conditions, morphology, in vitro cytotoxicity, cellular internalization, and extracellular metabolomic profile to evaluate their suitability for the targeting and imaging of breast cancer cells.

\section{Materials and Methods}

\subsection{Chemicals, Materials, and Cells}

Acetic acid (97.0\%, Sigma-Aldrich (St. Louis, MO, USA)), chitosan (CS, purified powder, MW 15,000, $>85 \%$ degree of deacetylation, viscosity $>90 \mathrm{cPs}$ at $1 \%$ solution, Polysciences (Warrington, PA, USA)), Azpack ${ }^{\mathrm{TM}}$ cotton wool (BP grade, Fisher Scientific (Hampton, NH, USA)), dimethyl sulfoxide (DMSO, >99\%, LabScan (Bangkok, Thailand)), 3-(4,5-dimethylthiazolyl-2)-2,5-diphenyltetrazolium bromide (MTT, 98\%, Sigma-Aldrich (St. Louis, MO, USA)), 1-ethyl-3-(3-dimethylaminopropyl)carbodiimide (EDC, $\geq 98.0 \%$, Sigma-Aldrich (St. Louis, MO, USA)), fluorescein isothiocyanate (FITC, isomer I, 90\%, Sigma-Aldrich (St. Louis, MO, USA)), folic acid (FA, 97.0\%, Sigma-Aldrich (St. Louis, MO, USA)), methanol (99.9\%, Fisher Chemical (Hampton, NH, USA)), phosphate buffered saline (PBS, pH 7.2, Sigma-Aldrich (St. Louis, MO, USA)), sodium hydroxide (99.0\%, Fisher Chemical (Hampton, NH, USA)), and phosphotungstic acid hydrate (HPW, p.a., Carl Roth (Karlsruhe, Germany)) were used as received. Other chemicals and solvents were of laboratory grade. 
RPMI 1640 medium, fetal bovine serum (FBS), L-glutamine, penicillin/streptomycin, fungizone (250 $\mathrm{U} \mathrm{mL}^{-1}$ ) and trypsin-ethylenediaminetetraacetic acid (EDTA) (0.25\% trypsin and $1 \mathrm{mM}$ EDTA) were purchased from Gibco ${ }^{\circledR}$ (Life Technologies, Carlsbad, CA, USA). Type 1 ultrapure water (resistivity of $18.2 \mathrm{M} \Omega \mathrm{cm}\left(25^{\circ} \mathrm{C}\right)$ ) was filtered by a Simplicity ${ }^{\circledR}$ Water Purification System (Merck Millipore, Darmstadt, Germany). The Spectra/Por ${ }^{\circledR}$ regenerated cellulose dialysis membranes (MWCO 6-8 kDa) were purchased from Daigger Scientific (Hamilton, NJ, USA). The MDA-MB-231 breast cancer cells were obtained from the American Type Culture Collection (ATCC, Manassas, VA, USA).

\subsection{Preparation of Cellulose Nanocrystals (CNCs)}

The CNCs were prepared via acid hydrolysis with phosphotungstic acid according to a modified literature protocol [29]. In a typical procedure, $322 \mathrm{~g}$ of HPW (111 mmol) and water $(110 \mathrm{~mL})$ were placed in a $500 \mathrm{~mL}$ three-neck round bottom flask equipped with a reflux condenser. Then, the mixture was heated to $90{ }^{\circ} \mathrm{C}$ and thoroughly washed cellulose cotton fibers ( $9.0 \mathrm{~g}$, repeated washing with distilled water to remove impurities) were added in small portions. To achieve hydrolysis of the cotton fibers, the mixture was stirred for $48 \mathrm{~h}$ under reflux. After cooling to room temperature under vigorous stirring, the mixture was transferred to a $3 \mathrm{~L}$ extraction funnel. Diethyl ether $(500 \mathrm{~mL})$ and water $(250 \mathrm{~mL})$ were added, resulting in the formation of three phases (heaviest phase: HPW/ethanol/water, medium phase: aqueous, upper phase: ethanol). The medium aqueous phase was separated, and the CNCs were purified by repeated centrifugation and washing with $\mathrm{NaOH}(0.1 \mathrm{M})$ and distilled water to remove traces of tungstate. The average yield after freeze-drying (5 experiments) was $86.3 \pm 3.1 \%$.

The obtained CNCs have an elemental composition of $40.3 \pm 0.4 \%$ of carbon (C), $5.4 \pm 0.1 \%$ of hydrogen $(\mathrm{H})$ and $54.3 \pm 0.5 \%$ of oxygen $(\mathrm{O})$ determined by elemental analysis (LECO TruSpec 630-200-200 CHNS, LECO Corporation, Michigan, USA), dimensions of $45 \pm 12 \mathrm{~nm}$ (diameter) and $364 \pm 74 \mathrm{~nm}$ (length) (micrographs acquired on a HRSEM-SE SU-70 microscope, Hitachi High-Technologies Corporation, Tokyo, Japan), and zeta $(\zeta)$-potential of $-11.5 \pm 0.7 \mathrm{mV}$ at pH 7 (Zetasizer Nano ZS, Malvern Panalytical, Cambridge, UK).

\subsection{Synthesis of the FA-CS-FITC Derivative}

Firstly, CS ( $\zeta$-potential of $+68.4 \pm 2.1 \mathrm{mV}$ at $\mathrm{pH} 3$ ) was functionalized with folic acid (i.e., CS-FA derivative) following the methodology described by Lee et al. [30] with some modifications. Briefly, EDC (20 mg) was added to an FA solution (20 mg in $10 \mathrm{~mL}$ DMSO) and allowed to react for $90 \mathrm{~min}$ at room temperature to activate the carboxylic groups of FA. This solution was then added dropwise to a CS solution (100 mg in $20 \mathrm{~mL}$ of $1 \mathrm{M}$ acetic acid aqueous solution) under magnetic stirring, in an ice bath, and the $\mathrm{pH}$ was adjusted to 6 using an aqueous solution of $\mathrm{NaOH}(1 \mathrm{M})$. The reaction mixture was kept under stirring over $48 \mathrm{~h}$ at room temperature in the dark. The CS-FA derivative was dialyzed in distilled water for three days to remove the unreacted FA, followed by freeze-drying, which generated a yellowish solid with an elemental composition of $47.9 \pm 0.4 \%$ of $C$, $6.2 \pm 0.3 \%$ of $\mathrm{H}, 33.0 \pm 0.5 \%$ of $\mathrm{O}$, and $12.9 \pm 0.3 \%$ of nitrogen $(\mathrm{N})$, and a $\zeta$-potential value of $+57.0 \pm 4.4 \mathrm{mV}$ at $\mathrm{pH} 3$.

The FA-CS-FITC derivative was synthesized via an adapted method described by Huang et al. [31]. A solution of FITC (12 mg in $18 \mathrm{~mL}$ of methanol) was added dropwise to a solution of CS-FA (60 mg in $18 \mathrm{~mL}$ of $1 \mathrm{M}$ acetic acid aqueous solution) under magnetic stirring. The reaction mixture was allowed to react for $24 \mathrm{~h}$ at room temperature in the dark. Then, the $\mathrm{pH}$ of the solution was adjusted to 10 with an aqueous solution of $\mathrm{NaOH}$ (1 M). The solution containing the FA-CS-FITC derivative was dialyzed in distilled water for four days, followed by freeze-drying, which produced a light orange solid with an elemental composition of $50.0 \pm 0.5 \%$ of $C, 5.3 \pm 0.3 \%$ of $\mathrm{H}, 37.5 \pm 0.4 \%$ of $\mathrm{O}, 6.6 \pm 0.1 \%$ of $\mathrm{N}$ and $0.6 \pm 0.1 \%$ of sulphur $(\mathrm{S})$, and a $\zeta$-potential value of $+51.9 \pm 3.6 \mathrm{mV}$ at $\mathrm{pH} 3$. 


\subsection{Preparation of the CNC Nanosystems Functionalized with the FA-CS-FITC Derivative}

The CNCs were functionalized with the FA-CS-FITC derivative via electrostatic assembly. Briefly, a solution of FA-CS-FITC derivative $(1,2$ or $4 \mathrm{mg}$ in $40 \mathrm{~mL}$ of $1 \mathrm{M}$ acetic acid aqueous solution) was added dropwise to a suspension of CNCs (50 mg in $10 \mathrm{~mL}$ of ultrapure water), as summarized in Table 1 . The mixture stood for $1 \mathrm{~h}$ under magnetic stirring in the dark. Afterwards, the suspension was centrifuged (13,400 rpm, $10 \mathrm{~min}$, Megafuge 16R centrifuge (Thermo Scientific, Waltham, MA, USA)) and washed one time with $1 \mathrm{M}$ acetic acid aqueous solution and three times with ultrapure water, followed by freeze-drying, which yielded solid nanosystems with an orange coloration.

Table 1. Composition of the prepared CNCs/FA-CS-FITC nanosystems.

\begin{tabular}{ccccc}
\hline \multirow{2}{*}{ Nanosystems } & \multicolumn{2}{c}{ Nominal Composition ${ }^{\mathbf{a}}$} & \multicolumn{2}{c}{ Measured Composition ${ }^{\mathbf{b}}$} \\
\cline { 2 - 5 } & $\mathbf{W}_{\text {CNCs }}(\mathbf{m g})$ & $\mathbf{W}_{\text {FA-CS-FITC }}(\mathbf{m g})$ & $\mathbf{W}_{\text {FA-CS-FITC }}(\mathbf{m g})$ & $\mathbf{W}_{\text {FA-CS-FITC }} / \mathbf{W}_{\text {CNCs }}$ \\
\hline CNCs/FA-CS-FITC_1 & 50.0 & 1.01 & 0.65 & 0.013 \\
CNCs/FA-CS-FITC_2 & 50.0 & 1.99 & 1.43 & 0.029 \\
CNCs/FA-CS-FITC_3 & 50.0 & 4.09 & 2.97 & 0.059 \\
\hline
\end{tabular}

a The nominal composition is the initial mass of CNCs $\left(\mathrm{W}_{\mathrm{CNCS}}\right)$ and $\mathrm{CS}$ derivative ( $\mathrm{W}_{\text {FA-CS-FITC }}$ ). b The measured composition was indirectly determined by measuring the absorbance of the washing solutions of each nanosystem at $441 \mathrm{~nm}$ (calibration curve: $\left.y=2.2591 x-0.0141, R^{2}=0.9995\right)$, concentration range of the FA-CS-FITC derivative: $0.005-0.5 \mathrm{mg} \mathrm{mL}^{-1}$ ).

\subsection{Characterization Methods}

The Fourier transform infrared-attenuated total reflection (FTIR-ATR) spectra of all samples were collected in the solid-state in a Perkin-Elmer FT-IR System Spectrum BX spectrophotometer (Perkin-Elmer, Waltham, MA, USA), coupled with a single horizontal Golden Gate ATR cell (Specac ${ }^{\circledR}$, London, UK), using 32 scans at a resolution of $4 \mathrm{~cm}^{-1}$ in the wavenumber range of $600-4000 \mathrm{~cm}^{-1}$.

The optical spectra were recorded on a Thermo Scientific Evolution 220 UV-visible spectrophotometer (Thermo Fisher Scientific, Waltham, MA, USA) using 100 scans min $^{-1}$ with a bandwidth of $2 \mathrm{~nm}$ and an integration time of $0.3 \mathrm{~s}$ in the wavelength range of 250-600 nm. The CS and the FA-CS-FITC samples were analyzed in acidic aqueous solutions (1 $\mathrm{M}$ of acetic acid), and the FA and FITC samples were examined in DMSO and ethanol $\left(1 \mathrm{mg} \mathrm{mL}^{-1}\right)$, respectively. For the solid samples, namely the CNCs and CNCs/FA-CS-FITC_3 nanosystem, a Jasco V-560 UV-visible spectrophotometer (JASCO Corporation, Tokyo, Japan) was utilized also in the wavelength range of 250-600 nm.

The fluorescence emission spectra were obtained on a Horiba Jobin-Yvon FluoroMax-4 spectrofluorometer (Horiba Jobin-Yvon, Kyoto, Japan) with a $2.0 \mathrm{~nm}$ width of both excitation and emission slits, and an integration time of $0.1 \mathrm{~s}$ in the wavelength range of $500-650 \mathrm{~nm}$. The appropriate excitation wavelengths $\left(\lambda_{\text {ex }}\right)$ were obtained as the wavelength of maximum absorption as follows: $\lambda_{\mathrm{ex}}=450 \mathrm{~nm}$ for the FITC sample in ethanol $\left(1 \mathrm{mg} \mathrm{mL}^{-1}\right)$ and $\lambda_{\mathrm{ex}}=440 \mathrm{~nm}$ for the FA-CS-FITC in an acidic aqueous solution (ca. $1 \mathrm{mg} \mathrm{mL}^{-1}, 1 \mathrm{M}$ of acetic acid). The fluorescence spectrum of the solid CNCs/FA-CSFITC_3 nanosystem was recorded using a Jasco spectrofluorometer FP-8300 (JASCO Corporation, Tokyo, Japan) equipped with a xenon lamp, using a scan speed of $200 \mathrm{~nm} \mathrm{~min}{ }^{-1}$, bandwidth of excitation and emission of $5 \mathrm{~nm}$ and excitation wavelength of $495 \mathrm{~nm}$, also in the wavelength range of $500-650 \mathrm{~nm}$.

Zeta potential measurements were performed on a Malvern ZetaSizer Nano-ZS (Malvern Panalytical, Cambridge, UK) at room temperature and different media depending on the analyzed sample, as described above. All measurements were performed in triplicate.

Scanning transmission electron microscopy (STEM) images were acquired in a fieldemission gun (FEG) SEM Hitachi SU-70 microscope (Hitachi High-Technologies Corporation, Tokyo, Japan) operated at $15 \mathrm{kV}$. Samples were prepared by placing a drop of the suspensions of CNCs and CNCs/FA-CS-FITC_3 nanosystem directly onto carbon-coated copper grids and allowing the solvent to evaporate. The size (diameter and length) of the 
samples was determined by measuring over 100 rods (elongated nanostructures) for each sample, using the Fiji image processing software.

\subsection{Stability Tests}

The stability of the CNCs/FA-CS-FITC nanosystems was evaluated in simulated nonphysiological and physiological conditions, namely at $\mathrm{pH} 2.1$ (aqueous solution of $0.01 \mathrm{M}$ $\mathrm{HCl}$ ) and at pH 7.2 (PBS), for $24 \mathrm{~h}$ and $48 \mathrm{~h}$ [32]. Typically, $1 \mathrm{mg}$ of CNCs/FA-CS-FITC was added to vials containing $2 \mathrm{~mL}$ of the two media. Then, the suspensions were placed on an orbital shaker at $37^{\circ} \mathrm{C}$ in the dark for $24 \mathrm{~h}$ and $48 \mathrm{~h}$. After these periods, the suspensions were centrifugated at 13,400 rpm during $5 \mathrm{~min}$ (Megafuge 16R centrifuge, Thermo Scientific, Waltham, MA, USA). The absorbance spectra of the corresponding supernatants were recorded on a Thermo Scientific Evolution 220 UV-visible spectrophotometer (Thermo Scientific, Waltham, MA, USA) to quantify the amount of the derivative that was released (calibration curve: $y=2.2591 x-0.0141, R^{2}=0.9995$ ), concentration range of the FA-CSFITC derivative: $0.005-0.5 \mathrm{mg} \mathrm{mL}^{-1}$ ).

\subsection{Cell Culture}

MDA-MB-231 cells were cultured in RPMI culture medium with L-glutamine, without folic acid, supplemented with 10\% FBS, $2 \mathrm{mM}$ L-glutamine, 1\% penicillin-streptomycin $\left(10,000 \mathrm{U} \mathrm{mL}^{-1}\right)$, and $1 \%$ fungizone $\left(250 \mathrm{U} \mathrm{mL}^{-1}\right)$, at $37^{\circ} \mathrm{C}$ in a humidified atmosphere with $5 \% \mathrm{CO}_{2}$. Cells were daily observed for confluence and morphology using an inverted phase-contrast Eclipse TS100 microscope (Nikon, Tokyo, Japan). Sub-confluent cells were trypsinized with trypsin-EDTA $(0.25 \%$ trypsin, $1 \mathrm{mM}$ EDTA) when monolayers reached $70 \%$ of confluence.

\subsection{In Vitro Cytotoxicity Assay}

Cells were seeded in a 96-well plate at 20,000 cells / well and, after cell adhesion, the cell culture medium (in the 96 well plates) was replaced with fresh medium containing CNCs and CNCs/FA-CS-FITC nanosystems at 0, 12.5, 25, 50, 100, $200 \mu \mathrm{g} \mathrm{mL}^{-1}$ and then further incubated for $24 \mathrm{~h}$ at $37^{\circ} \mathrm{C}, 5 \% \mathrm{CO}_{2}$ humidified atmosphere.

At the end of the exposure time, $50 \mu \mathrm{L}$ of MTT solution $\left(1 \mathrm{mg} \mathrm{mL}^{-1}\right.$ in PBS pH 7.2) were added to the medium and cells were incubated for $4 \mathrm{~h}$. After that, the culture medium with MTT was removed and replaced by $150 \mu \mathrm{L}$ of DMSO and the plate was placed in a shaker for $2 \mathrm{~h}$ in the dark to completely dissolve the formazan crystals. The absorbance of the samples was measured with a BioTek Synergy HT plate reader (Synergy HT MultiMode, BioTeK, Winooski, VT, USA) at $570 \mathrm{~nm}$ with blank corrections. The cell viability was calculated with respect to the control cells:

$$
\text { Cell viability }(\%)=\left[\left(A b s_{\text {sample }}-A b s_{D M S O}\right) /\left(A b s_{\text {control }}-A b s_{D M S O}\right)\right] \times 100
$$

where $A b s_{\text {sample }}$ is the absorbance of the sample, $A b s_{D M S O}$ is the absorbance of the DMSO solvent and $A b s_{\text {control }}$ is the absorbance of the control.

\subsection{Cellular Uptake Assay}

Cells were seeded in 24-well plates at the concentration of 138,320 cells/well and then incubated for $24 \mathrm{~h}$ at $37{ }^{\circ} \mathrm{C}$ and $5 \% \mathrm{CO}_{2}$, for cell adherence. The culture medium was then replaced with $500 \mu \mathrm{L}$ of growth medium with pristine CNCs and CNCs/FA-CS-FITC nanosystems at $200 \mu \mathrm{g} \mathrm{mL}{ }^{-1}$, and the cells were incubated with the previously described culture conditions. Acellular medium and control cells (no treatment) were also incubated. After the $24 \mathrm{~h}$ incubation period, the medium was collected and $400 \mu \mathrm{L}$ aliquots were stored at $-80{ }^{\circ} \mathrm{C}$. Following washing with $250 \mu \mathrm{L}$ of PBS, the cells were trypsinized and $250 \mu \mathrm{L}$ of growth medium was added to neutralize trypsin. Two parameters, namely side-scattered light, and side-fluorescence light (excitation at $488 \mathrm{~nm}$ and measurement with a 530/30 band pass filter), were measured in an Attune ${ }^{\circledR}$ Acoustic Focusing Cytometer 
(ThermoFisher Scientific, Waltham, MA, USA). At least 50,000 cells were examined for each test. The data were analyzed by FlowJo software (FlowJo LLC, Ashland, OR, USA).

\subsection{Cellular Exometabolomics}

For the NMR analysis, the medium samples collected during the cellular uptake assay (described in Section 2.9) were processed to remove interfering proteins. Briefly, $700 \mu \mathrm{L}$ of cold methanol were added to $350 \mu \mathrm{L}$ of medium, followed by $30 \mathrm{~min}$ resting at $-20{ }^{\circ} \mathrm{C}$, centrifugation $(13,000 \times g, 20 \mathrm{~min})$ and vacuum drying of the supernatant. Dried samples were then reconstituted in $600 \mu \mathrm{L}$ of deuterated PBS $(100 \mathrm{mM}, \mathrm{pH} 7.4)$ and transferred into $5 \mathrm{~mm}$ NMR tubes.

The NMR spectra were acquired on a Bruker Avance III HD 500 NMR spectrometer (Bruker Corporation, Billerica, MA, USA) operating at $500.13 \mathrm{MHz}$ for ${ }^{1} \mathrm{H}$ observation using a $5 \mathrm{~mm}$ TXI probe. Standard $1 \mathrm{D}^{1} \mathrm{H}$ spectra with water pre-saturation (pulse program 'noesypr1d', Bruker library) were recorded with $32 \mathrm{k}$ points, $7002.801 \mathrm{~Hz}$ spectral width, a 2 s relaxation delay and 512 scans. Spectral processing (TopSpin 4.0.3, Bruker BioSpin) comprised cosine multiplication (ssb 2), zero-filling to $64 \mathrm{k}$ data points, manual phasing, baseline correction, and calibration to the TSP- $d 4$ signal $(\delta 0 \mathrm{ppm})$. Selected signals representative of the main metabolites detected were then integrated (Amix-Viewer 3.9.15, Bruker Biospin) and, for each metabolite, the fold change relative to the acellular medium was calculated for control and exposed groups to assess the magnitude of consumptions/secretions.

\subsection{Statistical Analysis}

Cellular viability, uptake and exometabolomics data were analyzed using the GraphPad Prism Software (GraphPad Software Inc., San Diego, CA, USA) with the data presented as the mean values \pm standard error. Where differences existed, the source of the differences at the $p<0.05$ significance level was identified by all pairwise multiple comparison procedures via the Tukey's test.

\section{Results and Discussion}

Nanosystems based on cellulose nanocrystals (CNCs) and a multifunctional chitosan (CS) derivative were prepared via the simple (and eco-friendly) physical adsorption of the CS derivative, containing targeting (folic acid, FA) and imaging (fluorescein isothiocyanate, FITC) ligands (i.e., FA-CS-FITC), on the surface of the CNCs (Figure 1). Herein, the FA vitamin was carefully chosen as a targeting agent given the over-expression of folate receptors (FRs) in several tumor cells (and under-expression in non-tumor cells) [9,33], while the FITC fluorophore was picked for being a widely used imaging probe for the flow cytometry assays [33]. Furthermore, the CNCs were selected for their elongated nanostructure and anionic surface charge [29], whereas the CS derivative was chosen for its imaging and targeting moieties, as well as the cationic surface charge due to the presence of the characteristic protonated amine groups of $\mathrm{CS}$ at an acidic $\mathrm{pH}$ [34]. The assembly of the CNCs/FA-CS-FITC nanosystems via non-covalent interactions was preferred to covalent bonding due to the milder reaction conditions, when compared with previous studies where the functionalization of the CNC nanosystems was performed with fairly toxic reagents $[20,22,23,25]$.

The opposite surface charge of these two polysaccharides enabled the facile physical adsorption [35] of the multifunctional CS derivative (i.e., FA-CS-FITC) on the surface of the elongated CNCs (Figure 1). The CNCs/FA-CS-FITC nanosystems were characterized in terms of structure, optical properties, fluorescence, stability in simulated physiological and non-physiological conditions, morphology, in vitro cytotoxicity, cellular internalization, and exometabolomics profile to evaluate their suitability for the targeting and imaging of breast cancer cells. 


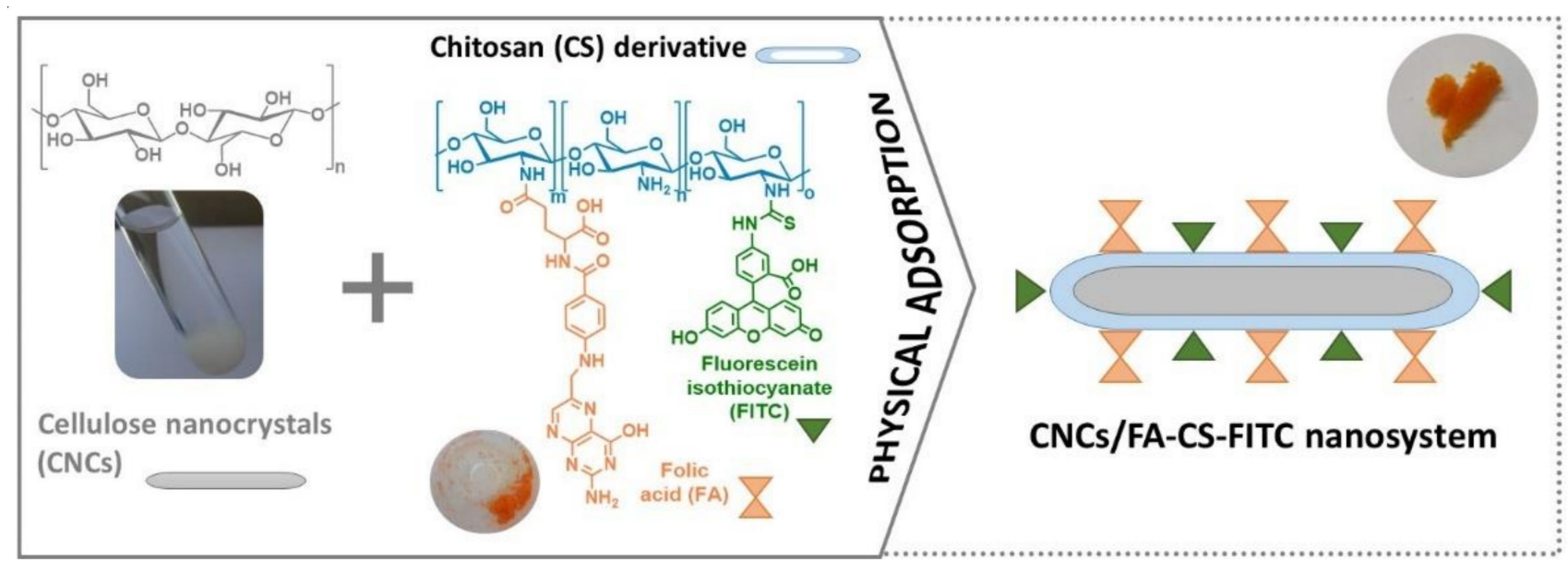

Figure 1. Scheme representing the preparation of the CNCs/FA-CS-FITC nanosystems.

\subsection{Preparation and Characterization of the CNCs/FA-CS-FITC Nanosystems}

The synthetic pathway to obtain the CNCs nanosystems with targeting and imaging functions (Figure 1) comprised three main steps. First, the CNCs were extracted from cellulose cotton fibers via acid hydrolysis with phosphotungstic acid [29]. Then, the FACS-FITC derivative was synthesized via a two-step pathway, where the CS was initially functionalized with FA by a carbodiimide-mediated amidation reaction, followed by the reaction of this intermediate with the isothiocyanate groups $(\mathrm{N}=\mathrm{C}=\mathrm{S})$ of the FITC to obtain the FA-CS-FITC derivative $[30,31]$. Lastly, the simple and eco-friendly physical adsorption of the FA-CS-FITC derivative ( $\zeta$-potential of $+51.9 \pm 3.6 \mathrm{mV}$ at $\mathrm{pH} 3)$ on the surface of the CNCs ( $\zeta$-potential of $-11.5 \pm 0.7 \mathrm{mV}$ at $\mathrm{pH} 7)$ generated the CNCs/FA-CS-FITC nanosystems (Figure 1). Herein, three CNCs nanosystems with different contents of the FA-CS-FITC derivative were prepared, namely CNCs/FA-CS-FITC_1 with a content of 13 $\mu \mathrm{g}$ of FA-CS-FITC per mg of CNCs, CNCs/FA-CS-FITC_2 with $29 \mu \mathrm{g} \mathrm{mg}^{-1}$ and CNCs/FACS-FITC_3 with $59 \mu \mathrm{g} \mathrm{mg}^{-1}$ (Table 1). The adsorption efficiencies of the FA-CS-FITC derivative on the surface of the CNCs (determined by UV-vis spectroscopy) were ca. $64 \%$ for CNCs/FA-CS-FITC_1, and around 72\% for both CNCs/FA-CS-FITC_2 and CNCs/FACS-FITC_3 (Table 1).

The first indication of the successful assembly process between the CNCs and the CS derivative was given by the color change of the elongated CNCs from white to an orange color, as illustrated in Figure 1. This was further corroborated by FTIR-ATR, UV-vis, and fluorescence spectroscopy, as exemplified in Figure 2 for the nanosystem with the higher content of the FA-CS-FITC derivative, i.e., CNCs/FA-CS-FITC_3 (Table 1).

The FTIR-ATR spectrum of the CNCs/FA-CS-FITC_3 nanosystem (Figure 2B) presents predominantly the characteristic vibrations of the CNCs at $3342 \mathrm{~cm}^{-1}(\mathrm{O}-\mathrm{H}$ stretching), $2902 \mathrm{~cm}^{-1}$ (C-H stretching), $1316 \mathrm{~cm}^{-1}$ (O-H in-plane bending), and $1032 \mathrm{~cm}^{-1}(\mathrm{C}-\mathrm{O}$ stretching) (Figure 2B) [36], but also those of the CS derivative, namely from: (i) chitosan at $3342 \mathrm{~cm}^{-1}$ (O-H and $\mathrm{N}-\mathrm{H}$ stretching), $1636 \mathrm{~cm}^{-1}$ ( $\mathrm{C}=\mathrm{O}$ stretching and $\mathrm{N}-\mathrm{H}$ bending), $1592 \mathrm{~cm}^{-1}$ (-NH 2 bending), $1380 \mathrm{~cm}^{-1}\left(-\mathrm{CH}_{2}\right.$ bending), 1078 and $1032 \mathrm{~cm}^{-1}$ (C-O stretching) [37]; (ii) folic acid at $1688 \mathrm{~cm}^{-1}$ ( $\mathrm{C}=\mathrm{O}$ stretching), 1602 and $1481 \mathrm{~cm}^{-1}$ ( $\mathrm{C}=\mathrm{C}$ aromatic) $\mathrm{cm}^{-1}$ (phenyl ring) [38], and (iii) FITC at 1545, 1458 and $1378 \mathrm{~cm}^{-1}$ (xanthene ring skeletal C-C stretching) [39-41], as depicted in Figure 2A. However, the majority of these absorption bands overlap because of the common functional groups of the individual components (i.e., CNCs, CS, FA and FITC). Worth noting here is the absence of the absorption bands at $1686 \mathrm{~cm}^{-1}$ (carboxyl moiety of FA [38]) and $2018 \mathrm{~cm}^{-1}$ (isothiocyanate moiety ( $\mathrm{N}=\mathrm{C}=\mathrm{S}$ ) of the FITC [39]), together with the appearance of the absorption band (ca. $1650 \mathrm{~cm}^{-1}$ ) assigned to the amide thioamide bonds [42], that confirm the covalent link between CS and FA [43], and CS and FITC [44], respectively, in agreement with data reported elsewhere [45]. 
A



C

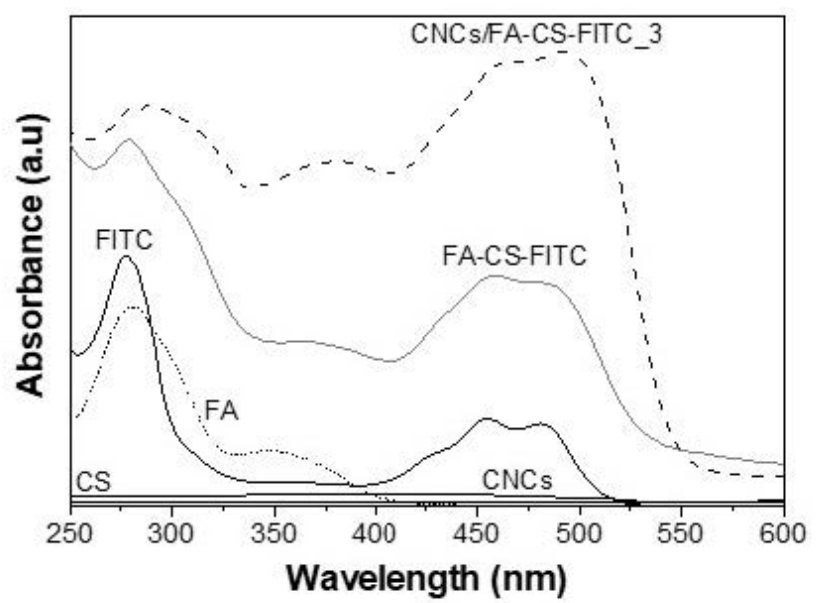

B



D

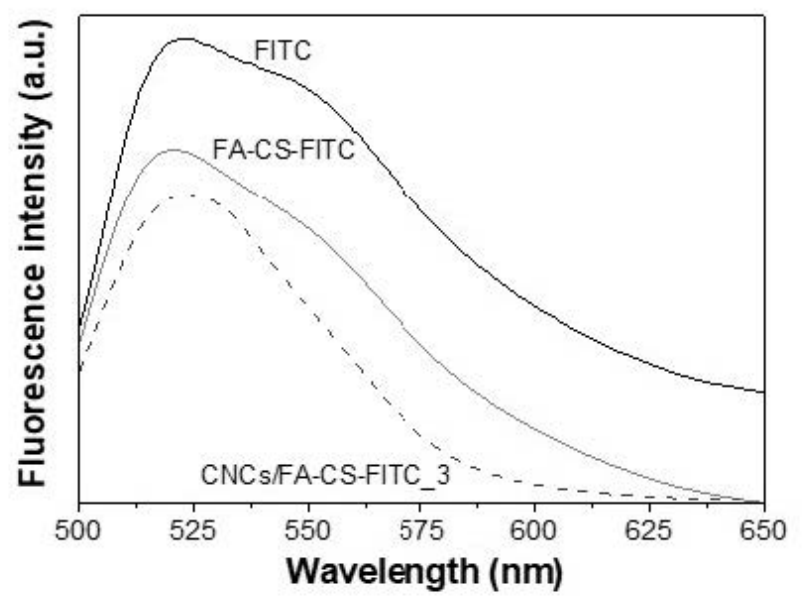

Figure 2. (A) FTIR-ATR spectra (vibrational modes: $v=$ stretching, $\delta=$ bending) of the pure CS, FA and FITC, (B) FTIR-ATR spectra of the pristine CNCs, FA-CS-FITC derivative and CNCs/FA-CS-FITC_3 nanosystem, (C) UV-vis spectra of CNCs, CS, FA, FITC, FA-CS-FITC derivative and CNCs/FA-CS-FITC_3 nanosystem, and (D) fluorescence emission spectra of the FITC, FA-CS-FITC derivative and CNCs/FA-CS-FITC_3 nanosystem.

The UV-vis spectrum of the CNCs/FA-CS-FITC_3 nanosystem (Figure 2C) exhibits only the characteristic bands of the CS derivative, given that the CNCs do not present any absorption in the UV and visible regions, as registered elsewhere [20,46]. On the other hand, the bands of the FA-CS-FITC derivative (Figure 2C) are typical of the FA (at ca. 285 and $356 \mathrm{~nm}$ ascribed to the $\pi-\pi^{*}$ and $\mathrm{n}-\pi^{*}$ transitions, respectively [38]) and FITC (at about 289, 462 and $490 \mathrm{~nm}[39,40]$ ) ligands since the pure CS polysaccharide does not display any absorption in the UV and visible regions [47]. Predictably, some of the absorption bands were red-shifted compared to those reported for the pure FA and FITC, which is an 
indication of the covalent bond between CS, FA and FITC in the FA-CS-FITC derivative, as described for other systems such as FA-polyaniline [38] and FITC-organoclay [39].

The fluorescence emission spectrum of the CNCs/FA-CS-FITC_3 nanosystem (Figure 2D) shows an absorption maximum at ca. $524 \mathrm{~nm}$, which mimics the emission fluorescence peak of the FA-CS-FITC derivative. This peak is characteristic of the FITC fluorophore that, as reported by Ghosh et al. [40], upon excitation at a wavelength of $490 \mathrm{~nm}$ presents a strong emission peaking at around $520 \mathrm{~nm}$. As anticipated, the pristine $\mathrm{CNCs}$ showed no emission in the wavelength range of the visible region. These results indicate that the $\mathrm{CNCs}$ nanosystems have fluorescent properties since the FITC fluorophore maintained its fluorescence. This behavior was expected given that the FITC is widely used to attach a fluorescent label mostly to polysaccharides (e.g., FITC-labelled CS [33,48], FITC-labelled CNCs [20,49], FITC-labelled dextran [40]) and proteins (e.g., FITC-labelled albumin [50]).

The success of the assembly process was additionally confirmed by testing the stability of the CNCs/FA-CS-FITC_3 nanosystem under simulated non-physiological and physiological $\mathrm{pH}$ conditions, namely $\mathrm{pH} 2.1$ for acidic medium [32] and $\mathrm{pH} 7.2$ for human blood plasma [51], respectively. Since these CNC nanosystems rely on the physical adsorption between the negatively charged CNCs and the cationic CS derivative, it is important to assess the potential release of FA-CS-FITC from the nanosystems to avoid ambiguous interpretations of the results or even unnecessary cytotoxic effects, which might hinder their applicability [52]. According to the obtained data, the amount of the CS derivative released from the CNCs/FA-CS-FITC_3 nanosystem is low at a non-physiologic $\mathrm{pH}$ with values of $6.6 \pm 0.8 \%$ and $8.4 \pm 0.5 \%$ for $24 \mathrm{~h}$ and $48 \mathrm{~h}$, respectively. At the physiological $\mathrm{pH} 7.2$, the release was slightly higher, with values of $11.0 \pm 0.1 \%$ and $14.5 \pm 0.1 \%$ for $24 \mathrm{~h}$ and $48 \mathrm{~h}$, respectively. Overall, the CNCs/FA-CS-FITC nanosystems present good stability and dispersibility in both $\mathrm{pH}$ conditions, which can be credited to the effective electrostatic interactions established between the anionic CNCs and the cationic FA-CS-FITC derivative.

The morphology and size of the CNCs nanosystems functionalized with the FA-CSFITC derivative were assessed by STEM (Figure 3). As anticipated, the pristine CNCs showed the typical rod-like morphology with dimensions of $45 \pm 12 \mathrm{~nm}$ (diameter) and $364 \pm 74 \mathrm{~nm}$ (length), analogous to the data described in the literature [29]. After the assembly process, the CNCs maintained the rod-like morphology, but their dimensions slightly increased to $57 \pm 15 \mathrm{~nm}$ (diameter) and $442 \pm 124 \mathrm{~nm}$ (length). This minor increase in the size range is clearly a direct result of the physical adsorption of the CS derivative on the surface of the CNCs, and it was also observed for other CNCs-based nanosystems [25,53].

Both the shape and size of the CNCs/FA-CS-FITC nanosystems are parameters of utmost importance due to the cell-size-dependent uptake of nanoparticles by the cells $[14,17]$. Thus, one can speculate that the elongated morphology of the CNCs/FA-CS-FITC nanosystems, together with their nanometric size, will not hinder the cellular internalization by the FR-positive breast cancer cells (i.e., MDA-MB-231 cell line), as will be discussed in the following paragraphs.

\subsection{Cellular Viability}

The in vitro cytotoxicity of the pristine CNCs and the CNCs/FA-CS-FITC nanosystems was evaluated in human breast adenocarcinoma cells (i.e., MDA-MB-231 cells) for $24 \mathrm{~h}$ at concentrations ranging from 12.5 to $200 \mu \mathrm{g} \mathrm{mL}^{-1}$ using the indirect MTT assay. The MDA-MB-231 cell line was selected for being often used as a model of triple-negative breast cancer cells [54] with over-expression of folate receptors [55], and for which the available therapeutic options are more scarce than other breast cancer subtypes [56]. 
A

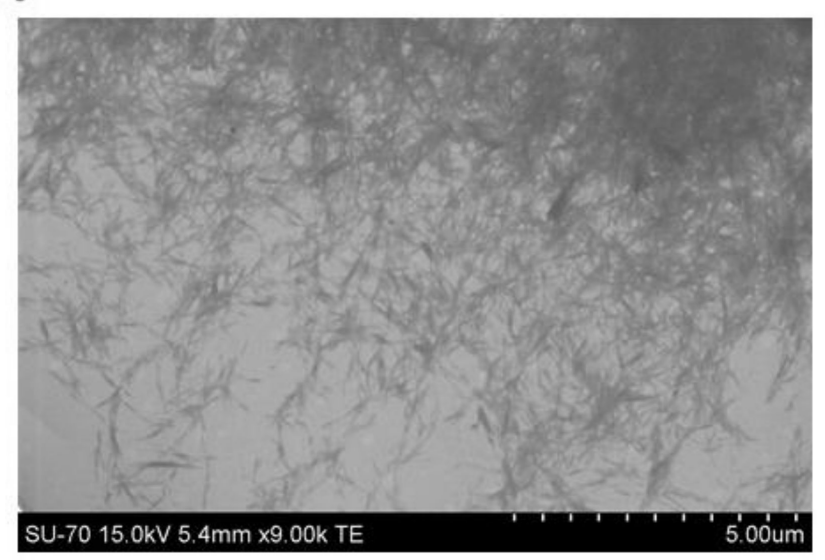

C

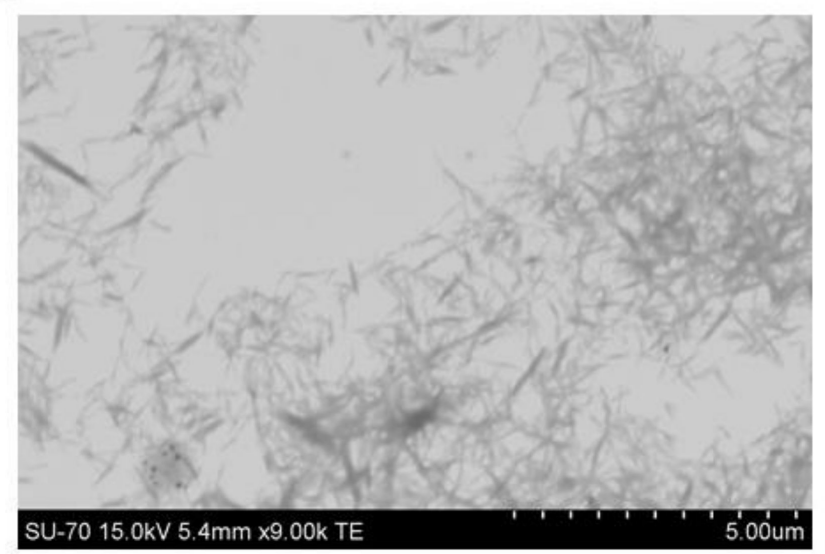

B



D



Figure 3. STEM micrographs $(\mathbf{A}, \mathbf{C})$ with the corresponding size histograms (diameter and length, $(\mathbf{B}, \mathbf{D})$ ) of the $(\mathbf{A}, \mathbf{B})$ pristine CNCs and (C,D) CNCs/FA-CS-FITC_3 nanosystem.

According to the data presented in Figure 4A, the cell viability of the MDA-MB-231 cells after $24 \mathrm{~h}$ of exposure to the pristine CNCs at five different concentrations $(12.5,25,50$, 100 and $200 \mu \mathrm{g} \mathrm{mL}^{-1}$ ) remained at the level of $100 \%$, meaning that the cell viability is not dose-dependent in the tested concentration range. This outcome for the pristine CNCs is consistent with the results found in the literature for this cell line [22], but also for other FR-positive human cancer cell lines, e.g., MDA-MB-468, KB, and PC-3 cells [22].

Regarding the CNCs/FA-CS-FITC nanosystems, the profile is the same and the cell viability is higher than $90 \%$ for all the tested concentrations. This confirms without a doubt that the three CNCs/FA-CS-FITC nanosystems are non-cytotoxic to the MDA-MB-231 cells at concentrations below $200 \mu \mathrm{g} \mathrm{mL}^{-1}$, with an in vitro cell viability quite above the $70 \%$ threshold [57]. These results are similar to those reported for other CNCs-based nanosystems with other tumor cell lines, such as the human breast adenocarcinoma MCF-7 cell line [58], and the A375 and M14 cells (malignant melanoma cell lines) [59].

The non-cytotoxicity of the three CNCs/FA-CS-FITC nanosystems for the tested concentration range evinces their potential to act as nanocarriers of imaging and therapeutic agents for targeted therapy, without inhibiting the viability of the FR-positive breast cancer cells. In this sense, the cellular internalization assays will be performed with the highest tested concentration, namely at $200 \mu \mathrm{g} \mathrm{mL}^{-1}$ of each of the CNCs/FA-CS-FITC nanosystems, as discussed in the following paragraphs. 
A

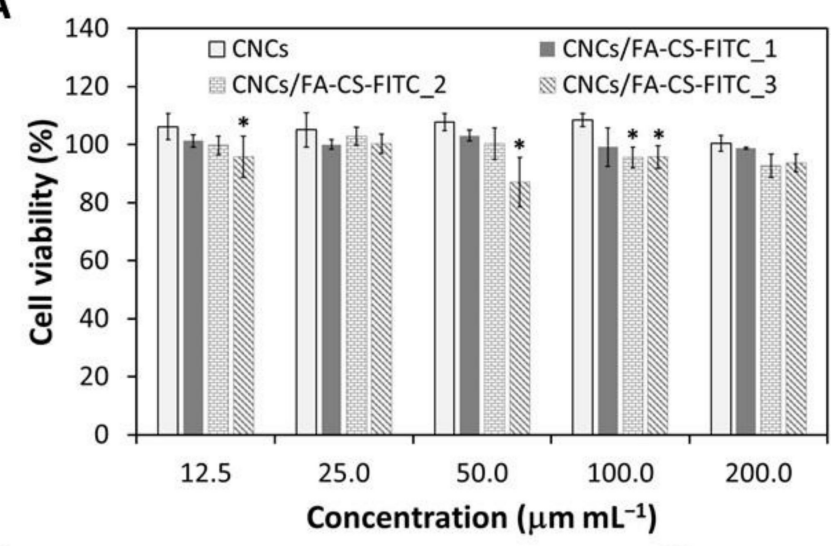

B

C
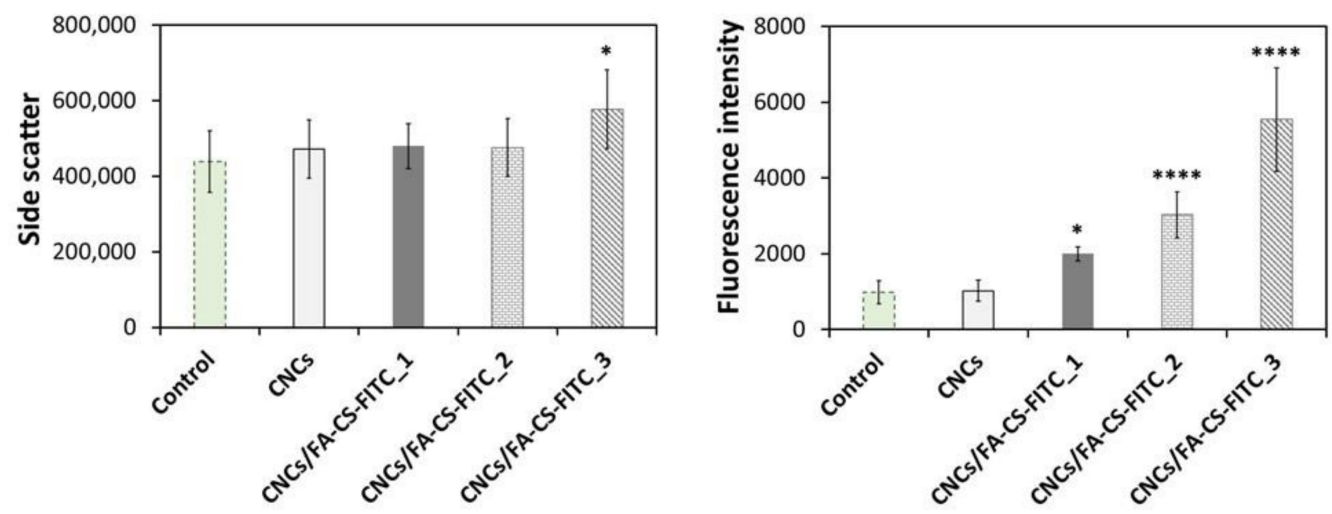

Figure 4. (A) Cell viability of the MDA-MB-231 cells after $24 \mathrm{~h}$ of exposure to the pristine CNCs and CNCs/FA-CS-FITC nanosystems, and flow cytometry data: (B) side-scattered light and (C) sidefluorescence light of the pristine CNCs and CNCs/FA-CS-FITC nanosystems for $24 \mathrm{~h}$ (the symbols * and ${ }^{* * * *}$ epitomize the means with a significant difference from the control at $p<0.05$ and $p<0.0001$ levels, respectively).

\subsection{Cellular Internalization}

The in vitro cellular internalization of the CNCs/FA-CS-FITC nanosystems by the MDA-MB-231 cells was studied by flow cytometry (side-scattered light (Figure 4B) and side-fluorescence light (Figure $4 \mathrm{C}$ )) for an exposure time of $24 \mathrm{~h}$. The data compiled in Figure $4 \mathrm{~B}$ shows that the incubation of the MDA-MB-231 cells in the presence of the pristine CNCs did not result in cell internalization, which is in line with the findings reported for this cell line [22], but also for other FR-positive human cancer cell lines, namely KB and MDA-MB-468 cells [22,24,25], and PC-3 cells [22].

In the case of the CNCs/FA-CS-FITC nanosystems, the ones with the lower content of the CS derivative, i.e., CNCs/FA-CS-FITC_1 (13 $\mu \mathrm{g}$ of FA-CS-FITC per mg of CNCs) and CNCs/FA-CS-FITC_2 (29 $\mu \mathrm{g}$ of FA-CS-FITC per mg of CNCs), showed a minor enhancement when compared to the control, and thus the cell internalization was minimal. In fact, only the CNCs/FA-CS-FITC_3 nanosystem ( $59 \mu \mathrm{g}$ of FA-CS-FITC per mg of CNCs) was significantly internalized by the FR-positive breast cancer cell line $(p<0.05)$.

Since these measurements are proportional to cell granularity or cell complexity and thus can be sometimes less sensitive [60], the fluorescence intensity of the cell population was also evaluated (Figure $4 \mathrm{C}$ ) by taking advantage of the existent FITC fluorophore probe in the CNCs/FA-CS-FITC nanosystems. Once again, the cells incubated in the presence of the pristine $\mathrm{CNCs}$ exhibited a fluorescence intensity matching the control, which agrees with the results shown in Figure 4B. On the contrary, the CNCs/FA-CS-FITC nanosystems displayed a significant increase in the fluorescence intensity (Figure 4C). Basically, it is 
possible to observe the augment of the fluorescence intensity with the increasing content of the CS derivative (i.e., FA-CS-FITC, Table 1), reaching a maximum 5-fold increase compared to the control. The growing cell internalization by the FR-positive breast cancer cells is credited to the increasing content of FA.

Notably, this outcome also validates that the size of the CNCs/FA-CS-FITC nanosystems (Figure 3) did not hamper in any way the effective internalization of these FA-target nanosystems by the FR-positive breast cancer cells, as is in fact shown with other CNCsbased nanosystems with FA ligands $[23,25,26]$.

\subsection{Cellular Exometabolomics}

The extracellular metabolomic profile of the MDA-MB-231 cells was studied by ${ }^{1} \mathrm{H}$ NMR spectroscopy to assess possible changes in the cells metabolic activity induced by the $24 \mathrm{~h}$ exposure to the pristine CNCs and the CNCs/FA-CS-FITC nanosystems $\left(200 \mu \mathrm{g} \mathrm{mL}{ }^{-1}\right)$. Figure 5A shows the characteristic ${ }^{1} \mathrm{H}$ NMR spectra of the MDA-MB-231 cell-conditioned medium and of the acellular culture medium incubated under identical conditions. Integration of the NMR signals representative of the main metabolites allowed the determination of the metabolite consumption and secretion by control and exposed cells, as summarized in Figure 5B.

The MDA-MB-231 control cells mainly consumed glucose and choline, along with some amino acids (glutamine, branched-chain amino acids, aromatic amino acids, and histidine), while excreting lactate, glutamate, alanine, and acetate (Figure 5B,C). These findings are similar to those reported by Guerra et al. [61] and highlight the fact that the MDA-MB-231 cell line, like most cancer cells, exhibits the classical Warburg effect with a high glucose uptake and lactate production, together with high glutaminolytic activity [62].

Upon exposure of the MDA-MB-231 cells to the CNCs, there were no changes in their metabolic activity, which is not unexpected, given that the pristine CNCs were poorly internalized (Figure 4B,C). However, when cells were incubated with the CNCs/FA-CSFITC nanosystems, slight but significant dose-dependent differences were found in choline uptake and acetate secretion (Figure 5B). The CNCs functionalized with intermediate and high FA concentrations (i.e., CNCs/FA-CS-FITC_2 and CNCs/FA-CS-FITC_3, respectively) caused a decrease in choline consumption and an increase in acetate release to the extracellular medium. Choline is an essential vitamin-like nutrient required for the de novo synthesis of membrane phospholipids, like phosphatidylcholine and sphingomyelin [63]. Various types of cancer cells, including breast cancer, display enhanced choline uptake and altered metabolism, to support fast proliferation and migratory capacity [64]. Hence, it is possible that the herein observed decrease in choline consumption by the cells incubated with the CNCs/FA-CS-FITC nanosystems reflects a lower synthesis of membrane lipids and a slower proliferation. This is consistent with the observed increase in the amount of acetate released by cells upon incubation with the nanosystems containing the highest concentrations of the FA-CS-FITC derivative (i.e., CNCs/FA-CS-FITC_2 and CNCs/FA-CS-FITC_3, Table 1). Indeed, besides glucose and glutamine, acetate provided as an extracellular nutrient or produced endogenously from pyruvate [65], may chiefly contribute to de novo lipid synthesis via conversion into acetyl-CoA by cytosolic and/or mitochondrial acetyl-CoA synthetases [66]. Hence, its release into the culture medium could reflect its lower intracellular utilization, possibly in relation to the downregulation of lipogenesis.

To summarize, the assembly of the CNCs/FA-CS-FITC nanosystems via physical adsorption was inspired by the possibility of using the opposite surface charge of the CNCs and the FA-CS-FITC derivative and originated non-cytotoxic nanosystems up to concentrations of $200 \mu \mathrm{g} \mathrm{mL}^{-1}$. Furthermore, and since the cellular uptake is a limiting factor for the efficacy of countless anticancer drugs, the presence of FA in the CNCs/FACS-FITC nanosystems promoted a higher cellular internalization towards FR-positive MDA-MB-231 breast cancer cells. Besides, mild alterations in the cells' exometabolome upon $24 \mathrm{~h}$ exposure to the CNCs/FA-CS-FITC nanosystems suggest an anti-proliferative effect, which may be beneficial in the context of cancer treatment. 
A

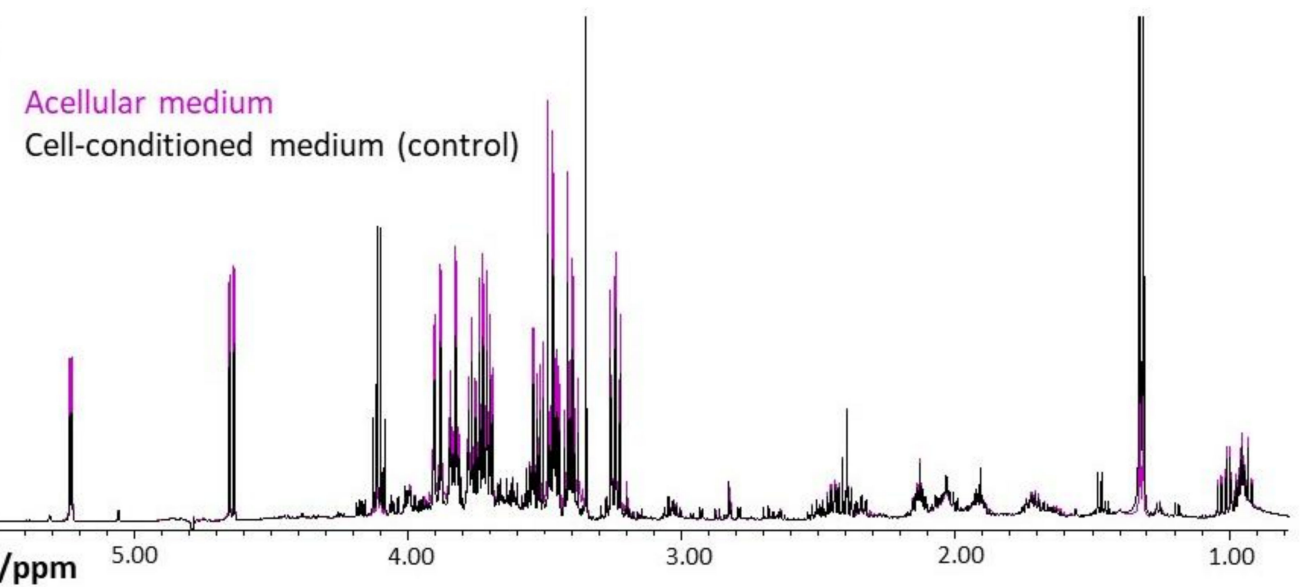

\section{B}

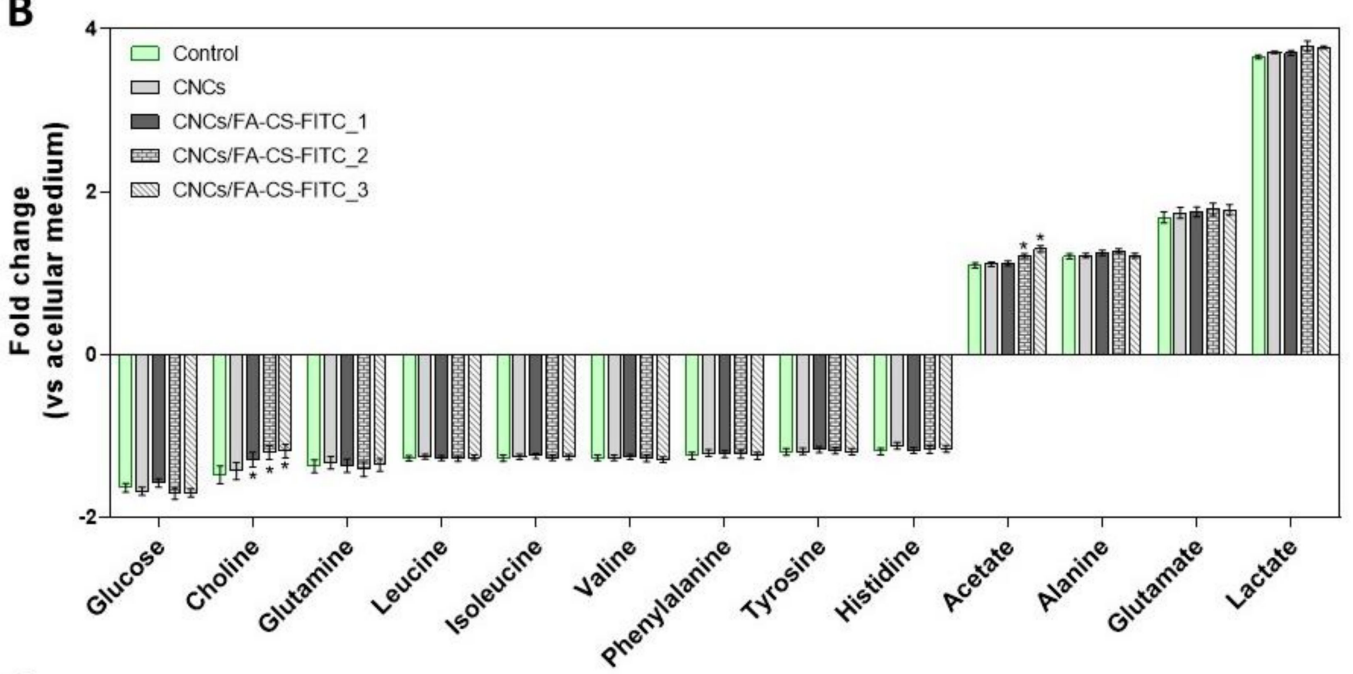

C



Figure 5. (A) ${ }^{1} \mathrm{H}$ NMR spectra of the acellular medium (pink) and supernatant from MDA-MB-231 breast cancer cells grown for $24 \mathrm{~h}$ (black), (B) variations in metabolites consumed (negative bars) and excreted (positive bars) by the MDA-MB-231 cells, under control conditions and upon treatment with $200 \mu \mathrm{g} \mathrm{mL}{ }^{-1}$ of CNCs, CNCs/FA-CS-FITC_1,CNCs/FA-CS-FITC_2 and CNCs/FA-CS-FITC_3 for $24 \mathrm{~h}$ (the symbol * represents the means with a significant difference from the control at $p<0.05$ ), and (C) chemical structures of the consumed (black) and excreted (green) metabolites.

Henceforth, the CNCs/FA-CS- FITC nanosystems can be exploited as nanocarriers of imaging and chemotherapeutics agents for active targeted therapy. In fact, the incorporation of, for instance, gold nanoparticles (with potential for photothermal cancer therapy [67]) into the CNCs/FA-CS-FITC nanosystems could be an option to engineer a nanocarrier with combined diagnostic and therapeutic capabilities, viz. a theranostic nanosystem [68]. 


\section{Conclusions}

In the present work, nanosystems composed of CNCs and a CS derivative were successfully developed and characterized. The physical adsorption of the CS derivative, containing a targeting ligand (FA) and an imaging agent (FITC), on the surface of the CNCs was an eco-friendly methodology to obtain CNCs-based nanosystems. The ensuing nanosystems displayed good stability in two distinct simulated non-physiological and physiological conditions ( $\mathrm{pH} 2.1$ and 7.2, respectively), as well as non-cytotoxicity towards MDA-MB-231 cells up to a concentration of $200 \mu \mathrm{g} \mathrm{mL}^{-1}$. The CNCs nanosystems showed a superior cellular internalization with a 5 -fold increase in the fluorescence intensity for the nanosystem with the greater content of FA, viz. concentration-dependent internalization by the FR-positive breast cancer cells. Additionally, the exometabolomics of MDA-MB231 cells exposed to the CNCs/FA-CS-FITC nanosystems revealed a mild impact on the metabolic activity of the cells, namely a decreased choline uptake and increased acetate release, which suggests an anti-proliferative effect. The overall data evidenced that the elongated CNCs /FA-CS-FITC nanosystems produced by an eco-friendly methodology have high affinity towards folate receptor-positive cancer cells with enhanced cellular internalization, and hence might be employed as nanocarriers with imaging properties for active targeted therapy.

Author Contributions: Conceptualization, C.S.R.F. and C.V.; investigation, R.J.B.P., N.S.L., G.G., G.H.R.d.S., P.O. and C.V.; resources, S.S., H.O., I.F.D. and C.S.R.F.; writing-original draft preparation, C.V. and R.J.B.P.; writing—review and editing, R.J.B.P., N.S.L., G.G., G.H.R.d.S., P.O., S.S., H.O., I.F.D., C.V. and C.S.R.F.; supervision, C.S.R.F.; funding acquisition, C.S.R.F., I.F.D., H.O. and S.S. All authors have read and agreed to the published version of the manuscript.

Funding: This work was developed within the scope of the projects CICECO-Aveiro Institute of Materials (UIDB/50011/2020 \& UIDP/50011/2020) and CESAM-Centre for Environmental and Marine Studies (UIDB/50017/2020 \& UIDP/50017/2020) financed by national funds through the Portuguese Foundation for Science and Technology (FCT)/MCTES. The research contract of R.J.B.P. was funded by national funds (OE), through FCT in the scope of the framework contract foreseen in the numbers 4, 5, and 6 of the article 23, of the Decree-Law 57/2016, of 29 August, changed by Law $57 / 2017$, of 19 July. FCT is also acknowledged for the doctoral grant to N.S.L. (SFRH/BD/140229/2018) and the research contracts under Scientific Employment Stimulus to H.O. (CEECIND/04050/2017), C.V. (CEECIND/00263/2018) and C.S.R.F. (CEECIND/00464/2017). FAPESP (Fundação de Amparo à Pesquisa do Estado de São Paulo) and the University of Aveiro are acknowledged for the doctoral grants to G.H.R.d.S. (2018/24814-0) and P.O. (BD/REIT/8623/2020), respectively. The NMR spectrometer is part of the National NMR Network (PTNMR), partially supported by Infrastructure Project $N^{\circ} 022161$ (co-financed by FEDER through COMPETE 2020, POCI and PORL and FCT through PIDDAC).

Conflicts of Interest: The authors declare no conflict of interest.

\section{References}

1. Vilela, C.; Pinto, R.J.B.; Pinto, S.; Marques, P.A.A.P.; Silvestre, A.J.D.; Freire, C.S.R. Polysaccharide Based Hybrid Materials: Metals and Metal Oxides, Graphene and Carbon Nanotubes, 1st ed.; Springer: Berlin/Heidelberg, Germany, 2018; ISBN 978-3-030-00346-3.

2. Klemm, D.; Heublein, B.; Fink, H.-P.; Bohn, A. Cellulose: Fascinating biopolymer and sustainable raw material. Angew. Chem. Int. Ed. 2005, 44, 3358-3393. [CrossRef] [PubMed]

3. Klemm, D.; Cranston, E.D.; Fischer, D.; Gama, M.; Kedzior, S.A.; Kralisch, D.; Kramer, F.; Kondo, T.; Lindström, T.; Nietzsche, S.; et al. Nanocellulose as a natural source for groundbreaking applications in materials science: Today's state. Mater. Today 2018, 21, 720-748. [CrossRef]

4. Almeida, T.; Silvestre, A.J.D.; Vilela, C.; Freire, C.S.R. Bacterial nanocellulose toward green cosmetics: Recent progresses and challenges. Int. J. Mol. Sci. 2021, 22, 2836. [CrossRef] [PubMed]

5. Vilela, C.; Silvestre, A.J.D.; Figueiredo, F.M.L.; Freire, C.S.R. Nanocellulose-based materials as components of polymer electrolyte fuel cells. J. Mater. Chem. A 2019, 7, 20045-20074. [CrossRef]

6. Heise, K.; Kontturi, E.; Allahverdiyeva, Y.; Tammelin, T.; Linder, M.B.; Nonappa; Ikkala, O. Nanocellulose: Recent fundamental advances and emerging biological and biomimicking applications. Adv. Mater. 2020, 33, 2004349. [CrossRef]

7. Meng, L.Y.; Wang, B.; Ma, M.G.; Zhu, J.F. Cellulose-based nanocarriers as platforms for cancer therapy. Curr. Pharm. Des. 2017, 23, 5292-5300. [CrossRef] 
8. Ul-islam, S.; Ul-islam, M.; Ahsan, H.; Ahmed, M.B.; Shehzad, A.; Fatima, A.; Sonn, J.K.; Lee, Y.S. Potential applications of bacterial cellulose and its composites for cancer treatment. Int. J. Biol. Macromol. 2021, 168, 301-309. [CrossRef]

9. Seabra, A.B.; Bernardes, J.S.; Fávaro, W.J.; Paula, A.J.; Durán, N. Cellulose nanocrystals as carriers in medicine and their toxicities: A review. Carbohydr. Polym. 2018, 181, 514-527. [CrossRef] [PubMed]

10. Silva, A.C.Q.; Vilela, C.; Santos, H.A.; Silvestre, A.J.D.; Freire, C.S.R. Recent trends on the development of systems for cancer diagnosis and treatment by microfluidic technology. Appl. Mater. Today 2020, 18, 100450. [CrossRef]

11. World Health Organization Fact Sheets: Cancer. Available online: https://www.who.int/news-room/fact-sheets/detail/cancer (accessed on 27 May 2021).

12. Ferlay, J.; Ervik, M.; Lam, F.; Colombet, M.; Mery, L.; Piñeros, M.; Znaor, A.; Soerjomataram, I.; Bray, F. Global Cancer Observatory: Cancer Today, Lyon, France: International Agency for Research on Cancer. Available online: https://gco.iarc.fr/today (accessed on 27 May 2021).

13. Trache, D.; Hussin, M.H.; Haafiz, M.K.M.; Thakur, V.K. Recent progress in cellulose nanocrystals: Sources and production. Nanoscale 2017, 9, 1763-1786. [CrossRef]

14. Gratton, S.E.A.; Ropp, P.A.; Pohlhaus, P.D.; Luft, J.C.; Madden, V.J.; Napier, M.E.; DeSimone, J.M. The effect of particle design on cellular internalization pathways. Proc. Natl. Acad. Sci. USA 2008, 105, 11613-11618. [CrossRef]

15. Blanco, E.; Shen, H.; Ferrari, M. Principles of nanoparticle design for overcoming biological barriers to drug delivery. Nat. Biotechnol. 2015, 33, 941-951. [CrossRef]

16. Liu, Y.; Tan, J.; Thomas, A.; Ou-Yang, D.; Muzykantov, V.R. The shape of things to come: Importance of design in nanotechnology for drug delivery. Ther. Deliv. 2012, 3, 181-194. [CrossRef] [PubMed]

17. Shang, L.; Nienhaus, K.; Nienhaus, G.U. Engineered nanoparticles interacting with cells: Size matters. J. Nanobiotechnol. 2014, 12, 5. [CrossRef] [PubMed]

18. Khine, Y.Y.; Stenzel, M.H. Surface modified cellulose nanomaterials: A source of non-spherical nanoparticles for drug delivery. Mater. Horiz. 2020, 7, 1727-1758. [CrossRef]

19. Senapati, S.; Mahanta, A.K.; Kumar, S.; Maiti, P. Controlled drug delivery vehicles for cancer treatment and their performance. Signal Transduct. Target. Ther. 2018, 3, 7. [CrossRef]

20. Dong, S.; Roman, M. Fluorescently labeled cellulose Nanocrystals for Bioimaging Applications. J. Am. Chem. Soc. 2007, 129, 13810-13811. [CrossRef] [PubMed]

21. Roman, M.; Dong, S.; Hirani, A.; Lee, Y.W. Cellulose nanocrystals for drug delivery. In Polysaccharide Materials: Performance by Design; Edgar, K.J., Heinze, T., Buchanan, C.M., Eds.; ACS Symposium Series; American Chemical Society: Washington, DC, USA, 2010; Volume 1017, pp. 81-91.

22. Dong, S.; Hirani, A.A.; Colacino, K.R.; Lee, Y.W.; Roman, M. Cytotoxicity and cellular uptake of cellulose nanocrystals. Nano Life 2012, 2, 1241006. [CrossRef]

23. Dong, S.; Cho, H.J.; Lee, Y.W.; Roman, M. Synthesis and cellular uptake of folic acid-conjugated cellulose nanocrystals for cancer targeting. Biomacromolecules 2014, 15, 1560-1567. [CrossRef] [PubMed]

24. Colacino, K.R.; Arena, C.B.; Dong, S.; Roman, M.; Davalos, R.V.; Lee, Y.W. Folate conjugated cellulose nanocrystals potentiate irreversible electroporation-induced cytotoxicity for the selective treatment of cancer cells. Technol. Cancer Res. Treat. 2015, 14, 757-766. [CrossRef]

25. Bittleman, K.R.; Dong, S.; Roman, M.; Lee, Y.W. Folic acid-conjugated cellulose nanocrystals show high folate-receptor binding affinity and uptake by KB and breast cancer cells. ACS Omega 2018, 3, 13952-13959. [CrossRef] [PubMed]

26. Raja, S.; Hamouda, A.E.I.; De Toledo, M.A.S.; Hu, C.; Bernardo, M.P.; Schalla, C.; Leite, L.S.F.; Buhl, E.M.; Dreschers, S.; Pich, A.; et al. Functionalized cellulose nanocrystals for cellular labeling and bioimaging. Biomacromolecules 2021, 22, 454-466. [CrossRef] [PubMed]

27. Tortorella, S.; Buratti, V.V.; Maturi, M.; Sambri, L.; Franchini, M.C.; Locatelli, E. Surface-modified nanocellulose for application in biomedical engineering and nanomedicine: A review. Int. J. Nanomed. 2020, 15, 9909-9937. [CrossRef]

28. Babu, A.; Ramesh, R. Multifaceted applications of chitosan in cancer drug delivery and therapy. Mar. Drugs 2017, 15, 96. [CrossRef] [PubMed]

29. Liu, Y.; Wang, H.; Yu, G.; Yu, Q.; Li, B.; Mu, X. A novel approach for the preparation of nanocrystalline cellulose by using phosphotungstic acid. Carbohydr. Polym. 2014, 110, 415-422. [CrossRef] [PubMed]

30. Lee, D.; Lockey, R.; Mohapatra, S. Folate receptor-mediated cancer cell specific gene delivery using folic acid-conjugated oligochitosans. J. Nanosci. Nanotechnol. 2006, 6, 2860-2866. [CrossRef] [PubMed]

31. Huang, Y.; Boamah, P.O.; Gong, J.; Zhang, Q.; Hua, M.; Ye, Y. Gd(III) complex conjugate of low-molecular-weight chitosan as a contrast agent for magnetic resonance/fluorescence dual-modal imaging. Carbohydr. Polym. 2016, 143, 288-295. [CrossRef] [PubMed]

32. Tobaldi, E.; Dovgan, I.; Mosser, M.; Becht, J.-M.; Wagner, A. Structural investigation of cyclo-dioxo maleimide cross-linkers for acid and serum stability. Org. Biomol. Chem. 2017, 15, 9305-9310. [CrossRef]

33. Caprifico, A.E.; Polycarpou, E.; Foot, P.J.S.; Calabrese, G. Biomedical and pharmacological uses of fluorescein isothiocyanate chitosan-based nanocarriers. Macromol. Biosci. 2021, 21, 2000312. [CrossRef]

34. Anitha, A.; Sowmya, S.; Kumar, P.T.S.; Deepthi, S.; Chennazhi, K.P.; Ehrlich, H.; Tsurkan, M.; Jayakumar, R. Chitin and chitosan in selected biomedical applications. Prog. Polym. Sci. 2014, 39, 1644-1667. [CrossRef] 
35. Vilela, C.; Figueiredo, A.R.P.; Silvestre, A.J.D.; Freire, C.S.R. Multilayered materials based on biopolymers as drug delivery systems. Expert Opin. Drug Deliv. 2017, 14, 189-200. [CrossRef]

36. Foster, E.J.; Moon, R.J.; Agarwal, U.P.; Bortner, M.J.; Bras, J.; Camarero-Espinosa, S.; Chan, K.J.; Clift, M.J.D.; Cranston, E.D.; Eichhorn, S.J.; et al. Current characterization methods for cellulose nanomaterials. Chem. Soc. Rev. 2018, 47, 2609-2679. [CrossRef] [PubMed]

37. Fonseca, D.F.S.; Carvalho, J.P.F.; Bastos, V.; Oliveira, H.; Moreirinha, C.; Almeida, A.; Silvestre, A.J.D.; Vilela, C.; Freire, C.S.R. Antibacterial multi-layered nanocellulose-based patches loaded with dexpanthenol for wound healing applications. Nanomaterials 2020, 10, 2469. [CrossRef]

38. Chakraborty, P.; Bairi, P.; Roy, B.; Nandi, A.K. Improved mechanical and electronic properties of co-assembled folic acid gel with aniline and polyaniline. ACS Appl. Mater. Interfaces 2014, 6, 3615-3622. [CrossRef] [PubMed]

39. Lee, Y.-C.; Lee, T.; Han, H.; Go, W.J.; Yang, J.; Shin, H. Optical properties of fluorescein-labeled organoclay. Photochem. Photobiol. 2010, 86, 520-527. [CrossRef]

40. Ghosh, S.K.; Ali, M.; Chatterjee, H. Studies on the interaction of fluorescein isothiocyanate and its sugar analogues with cetyltrimethylammonium bromide. Chem. Phys. Lett. 2013, 561-562, 147-152. [CrossRef]

41. Wang, L.; Roitberg, A.; Meuse, C.; Gaigalas, A.K. Raman and FTIR spectroscopies of fluorescein in solutions. Spectrochim. Acta Part A Mol. Biomol. Spectrosc. 2001, 57, 1781-1791. [CrossRef]

42. Bellamy, L.J. The Infrared Spectra of Complex Molecules, 3rd ed.; Chapman and Hall, Ltd.: London, UK, 1975; ISBN 041-2-138-506.

43. Alupei, L.; Lisa, G.; Butnariu, A.; Desbrières, J.; Cadinoiu, A.N.; Peptu, C.A.; Calin, G.; Popa, M. New folic acid-chitosan derivative based nanoparticles-Potential applications in cancer therapy. Cellul. Chem. Technol. 2017, 51, 631-648.

44. Elshoky, H.A.; Salaheldin, T.A.; Ali, M.A.; Gaber, M.H. Ascorbic acid prevents cellular uptake and improves biocompatibility of chitosan nanoparticles. Int. J. Biol. Macromol. 2018, 115, 358-366. [CrossRef]

45. Nawaz, A.; Wong, T.W. Chitosan-carboxymethyl-5-fluorouracil-folate conjugate particles: Microwave modulated uptake by skin and melanoma cells. J. Investig. Dermatol. 2018, 138, 2412-2422. [CrossRef]

46. Filpponen, I.; Sadeghifar, H.; Argyropoulos, D.S. Photoresponsive cellulose nanocrystals. Nanomater. Nanotechnol. $2011,1,34-43$. [CrossRef]

47. Pinto, R.J.B.; Fernandes, S.C.M.; Freire, C.S.R.; Sadocco, P.; Causio, J.; Neto, C.P.; Trindade, T. Antibacterial activity of optically transparent nanocomposite films based on chitosan or its derivatives and silver nanoparticles. Carbohydr. Res. 2012, $348,77-83$. [CrossRef]

48. Zhao, J.; Wu, J. Preparation and characterization of the fluorescent chitosan nanoparticle probe. Chin. J. Anal. Chem. 2006, 34, 1555-1559. [CrossRef]

49. Mahmoud, K.A.; Mena, J.A.; Male, K.B.; Hrapovic, S.; Kamen, A.; Luong, J.H.T. Effect of surface charge on the cellular uptake and cytotoxicity of fluorescent labeled cellulose nanocrystals. ACS Appl. Mater. Interfaces 2010, 2, 2924-2932. [CrossRef]

50. Mohanta, V.; Madras, G.; Patil, S. Albumin-mediated incorporation of water-insoluble therapeutics in layer-by-layer assembled thin films and microcapsules. J. Mater. Chem. B 2013, 1, 4819-4827. [CrossRef]

51. Marques, M.R.C.; Loebenberg, R.; Almukainzi, M. Simulated biological fluids with possible application in dissolution testing. Dissolution Technol. 2011, 18, 15-28. [CrossRef]

52. Gorgieva, S.; Vivod, V.; Maver, U.; Gradišnik, L.; Dolenšek, J.; Kokol, V. Internalization of (bis)phosphonate-modified cellulose nanocrystals by human osteoblast cells. Cellulose 2017, 24, 4235-4252. [CrossRef]

53. Hassan, M.L.; Moorefield, C.M.; Elbatal, H.S.; Newkome, G.R.; Modarelli, D.A.; Romano, N.C. Fluorescent cellulose nanocrystals via supramolecular assembly of terpyridine-modified cellulose nanocrystals and terpyridine-modified perylene. Mater. Sci. Eng. B 2012, 177, 350-358. [CrossRef]

54. Chavez, K.J.; Garimella, S.V.; Lipkowitz, S. Triple negative breast cancer cell lines: One tool in the search for better treatment of triple negative breast cancer. Breast Dis. 2011, 32, 35-48. [CrossRef]

55. Meier, R.; Henning, T.D.; Boddington, S.; Tavri, S.; Arora, S.; Piontek, G.; Rudelius, M.; Corot, C.; Daldrup-Link, H.E. Breast Cancers: MR imaging of folate-receptor expression with the folate-specific nanoparticle P1133. Radiology 2010, 255, 527-535. [CrossRef] [PubMed]

56. Thakur, V.; Kutty, R.V. Recent advances in nanotheranostics for triple negative breast cancer treatment. J. Exp. Clin. Cancer Res. 2019, 38, 430. [CrossRef]

57. ISO 10993-5:2009(E). Biological Evaluation of Medical Devices_Part 5: Tests for In Vitro Cytotoxicity; ISO: Geneva, Switzerland, 2009.

58. Hemraz, U.D.; Campbell, K.A.; Burdick, J.S.; Ckless, K.; Boluk, Y.; Sunasee, R. Cationic Poly(2-aminoethylmethacrylate) and Poly(N-(2-aminoethylmethacrylamide) modified cellulose nanocrystals: Synthesis, characterization, and cytotoxicity. Biomacromolecules 2015, 16, 319-325. [CrossRef]

59. Meschini, S.; Pellegrini, E.; Maestri, C.A.; Condello, M.; Bettotti, P.; Condello, G.; Scarpa, M. In vitro toxicity assessment of hydrogel patches obtained by cation-induced cross-linking of rod-like cellulose nanocrystals. J. Biomed. Mater. Res. Part B Appl. Biomater. 2020, 108, 687-697. [CrossRef]

60. Reardon, A.J.F.; Elliott, J.A.W.; McGann, L.E. Fluorescence as an alternative to light-scatter gating strategies to identify frozenthawed cells with flow cytometry. Cryobiology 2014, 69, 91-99. [CrossRef] 
61. Guerra, Â.R.; Soares, B.I.G.; Freire, C.S.R.; Silvestre, A.J.D.; Duarte, M.F.; Duarte, I.F. Metabolic effects of a Eucalyptus bark lipophilic extract on triple negative breast cancer and nontumor breast epithelial cells. J. Proteome Res. 2021, 20, 565-575. [CrossRef] [PubMed]

62. Zheng, J. Energy metabolism of cancer: Glycolysis versus oxidative phosphorylation (review). Oncol. Lett. 2012, 4, 1151-1157. [CrossRef] [PubMed]

63. Gibellini, F.; Smith, T.K. The Kennedy pathway-De novo synthesis of phosphatidylethanolamine and phosphatidylcholine. IUBMB Life 2010, 62, 414-428. [CrossRef]

64. Glunde, K.; Bhujwalla, Z.M.; Ronen, S.M. Choline metabolism in malignant transformation. Nat. Rev. Cancer 2011, 11, 835-848. [CrossRef] [PubMed]

65. Liu, X.; Cooper, D.E.; Cluntun, A.A.; Warmoes, M.O.; Zhao, S.; Reid, M.A.; Liu, J.; Lund, P.J.; Lopes, M.; Garcia, B.A.; et al. Acetate production from glucose and coupling to mitochondrial metabolism in mammals. Cell 2018, 175, 502-513. [CrossRef] [PubMed]

66. Kamphorst, J.J.; Chung, M.K.; Fan, J.; Rabinowitz, J.D. Quantitative analysis of acetyl-CoA production in hypoxic cancer cells reveals substantial contribution from acetate. Cancer Metab. 2014, 2, 23. [CrossRef] [PubMed]

67. Vines, J.B.; Yoon, J.H.; Ryu, N.E.; Lim, D.J.; Park, H. Gold nanoparticles for photothermal cancer therapy. Front. Chem. 2019, 7, 167. [CrossRef]

68. Jaymand, M. Chemically modified natural polymer-based theranostic nanomedicines: Are they the golden gate toward a de novo clinical approach against cancer? ACS Biomater. Sci. Eng. 2020, 6, 134-166. [CrossRef] 